\title{
Role of Central Alpha-1 Adrenoceptors in Canine Narcolepsy
}

\author{
Emmanuel Mignot, Christian Guilleminault, Scott Bowersox, Alain Rappaport, and William C. Dement
}

Sleep Disorders Center, Stanford University School of Medicine, Palo Alto, California 94304

\begin{abstract}
The role of central alpha-1 adrenergic receptors in cataplexy was investigated in genetically narcoleptic Doberman pinschers. Treatment of narcoleptic dogs with $25-600 \mu \mathrm{g} / \mathrm{kg}$ prazosin, a selective alpha-1 adrenergic receptor blocker, exacerbated cataplexy, whereas treatment with the alpha-1 agonist, methoxamine, ameliorated it. Subsequent studies showed that the beneficial effects of classical treatments of human narcolepsy (amphetamines and tricyclic antidepressants) are antagonized by prazosin, suggesting that these drugs are active through an indirect alpha-1 stimulation (via an increase of norepinephrine in the synaptic cleft). Other studies confirmed that the observed effects were not due to peripheral alpha-1 cardiovascular involvement. Atropine, a central anticholinergic agent, but not methylatropine, a peripheral one, completely suppressed the prazosin effect, which suggests that adrenergic and cholinergic systems act sequentially and not independently to generate cataplexy. Little is known about the physiological role of central alpha-1 adrenoceptors. This series of experiments implicates these receptors in narcolepsy-cataplexy.
\end{abstract}

\section{Introduction}

Human narcolepsy is a disabling sleep disorder of unknown origin, characterized by sudden attacks of partial or complete flaccid paralysis (cataplexy) and excessive daytime sleepiness. These attacks can strike spontaneously or be elicited by emotional experiences such as laughter, excitement, or fear. Sleep recording studies in narcoleptic patients show an abnormally rapid transition from wake to rapid eye movement (REM) ${ }^{1}$ sleep during the day and a drastically shortened REM latency at night (1). Since a state of muscular paralysis similar to cataplexy normally occurs during REM sleep, narcolepsy is considered an REM sleep disorder (1).

Considerable attention has centered on the role of central cholinergic systems in the regulation of REM sleep. Cataplexy and REM sleep are controlled by known cholinergic mechanisms located in the brainstem (2-7). Cholinergic neurons of the dorsal pontine tegmentum tonically inhibit muscle tone

Address reprint requests to Dr. Christian Guilleminault, Sleep Disorders Center, Stanford University School of Medicine, 701 Welch Road, Suite 2226, Palo Alto, CA 94304.

Received for publication 30 October 1987 and in revised form 4 April 1988

1. Abbreviations used in this paper: DBP, diastolic blood pressure; $\mathrm{E}_{\max }$, maximal effect; FECT, food-elicited cataplexy test; HR, heart rate; REM, rapid eye movement; SBP, systolic blood pressure.

J. Clin. Invest.

(C) The American Society for Clinical Investigation, Inc. 0021-9738/88/09/0885/10 $\$ 2.00$

Volume 82, September 1988, 885-894 during REM sleep. This muscle inhibition involves projections to the reticular formation in the medial medulla and from there to motor neurons in the spinal cord (2-7). Consistent with these anatomical findings, central cholinergic stimulation by physostigmine or arecoline has been reported to aggravate the symptoms in narcoleptic dogs, whereas central anticholinergic drugs, such as atropine or scopolamine, improve them (8). The use of anticholinergic drugs has, however, been very disappointing in human narcolepsy, particularly because of their numerous side effects.

The pharmacological manipulations of the central cholinergic network have been coupled with investigations of the role of monoamines in controlling REM sleep (9-11) and cataplexy. Noncholinergic, monoaminergic (especially norepinephrine) reuptake blockers (tricyclic antidepressants, viloxazine, and nisoxetine) and monoamine-releasing drugs (amphetamine and methylphenidate) are REM sleep suppressants and have beneficial effects in human and canine narcolepsy (8). However, it is difficult to assess which of their multiple pharmacological actions is responsible for their therapeutic effect and/or side effects. All these drugs act presynaptically on monoaminergic systems, and supposedly increase norepinephrine levels in the synaptic cleft. If such an increase in norepinephrine takes place, a postsynaptic adrenoceptor stimulation should occur, and such stimulation is probably involved in the therapeutic effects seen in narcoleptics.

Reports of changes in REM sleep in animals (12-15) and humans (16) after treatment with alpha-1 adrenergic agents (increase with blockade and decrease with stimulation) provided further rationale for our hypothesis. The role of central alpha-1 mechanisms in narcolepsy was examined by in vivo pharmacology in narcoleptic Doberman pinschers, an autosomal recessive animal model of human narcolepsy $(8,17-19)$.

\section{Methods}

Animals. Dogs were exposed to a 12/12 dark/light cycle. They had free access to food between 1300 and 0700 hours. Changes in cataplexy, $\mathrm{BP}$, and heart rate (HR) induced by pharmacological treatments were evaluated in six affected Dobermans, four controls, and four heterozygotes. The six homozygous Dobermans were four adults (3-7 yr) and two puppies $(6 \mathrm{mo})$. Their mean age and weight were $3.1 \mathrm{yr}$ and 18.7 $\mathrm{kg}$, respectively. Heterozygous and control Dobermans were all adult dogs ( $>8 \mathrm{mo}$ old) and had no attacks. Mean age and weight of heterozygous dogs were $10.8 \mathrm{mo}$ and $26.0 \mathrm{~kg}$. All control Dobermans were at least 11 mo old (two were born at an unknown date; mean weight was $28.1 \mathrm{~kg})$.

Food-elicited cataplexy test. The food-elicited cataplexy test (FECT) was used for the pharmacological investigations (8). Food precipitates multiple cataplectic attacks in these animals, sometimes followed by REM sleep. In our experimental procedure, 12 successive pieces of wet food $\left(1 \mathrm{~cm}^{3}\right)$ were placed on the floor and spaced $30 \mathrm{~cm}$ apart. Dogs were previously trained to eat the food one piece after another. The experimenter recorded $(a)$ the time required for the dog to eat all the pieces of food (elapsed time) and $(b)$ the number of complete and partial cataplectic attacks. An attack was considered complete when the dog dropped to the floor with head resting on the 
Table I. Effect of Placebo, Prazosin, and Methoxamine on Food-elicited Cataplexy Test

\begin{tabular}{|c|c|c|c|c|c|}
\hline & \multicolumn{4}{|c|}{ Time (hours) } & \\
\hline & 0 & 2 & 4 & 8 & \\
\hline \multicolumn{6}{|l|}{ Controls $(n=4)$} \\
\hline \multicolumn{6}{|l|}{ Placebo } \\
\hline Elapsed time $(s)$ & $12.3 \pm 1.3$ & $11.8 \pm 2.4$ & $11.8 \pm 1.3$ & $12.2 \pm 1.2$ & \\
\hline \multicolumn{6}{|l|}{ Prazosin $(600 \mu g / k g)$} \\
\hline Elapsed time $(s)$ & $12.8 \pm 1.1$ & $12.2 \pm 0.7$ & $11.8 \pm 0.6$ & $12.1 \pm 0.6$ & \\
\hline \multicolumn{6}{|l|}{ Heterozygotes $(n=4)$} \\
\hline \multicolumn{6}{|l|}{ Placebo } \\
\hline Elapsed time $(s)$ & $11.3 \pm 0.4$ & $11.6 \pm 0.2$ & $11.2 \pm 0.5$ & $11.4 \pm 0.3$ & \\
\hline \multicolumn{6}{|l|}{ Prazosin $(600 \mu g / k g)$} \\
\hline Elapsed time $(s)$ & $11.3 \pm 0.4$ & $11.5 \pm 0.3$ & $11.4 \pm 0.3$ & $11.2 \pm 0.3$ & \\
\hline \multicolumn{6}{|c|}{ Homozygotes $(n=6)$} \\
\hline \multicolumn{6}{|l|}{ Placebo } \\
\hline No. of attacks & $2.13 \pm 1.12$ & $1.87 \pm 1.06$ & $1.80 \pm 0.91$ & $1.35 \pm 0.60$ & \\
\hline Elapsed time $(s)$ & $33.2 \pm 12.0$ & $23.3 \pm 5.3$ & $21.9 \pm 5.0$ & $23.9 \pm 5.4$ & \\
\hline \multicolumn{6}{|l|}{ Prazosin $(2.5 \mu g / k g)$} \\
\hline No. of attacks & $2.83 \pm 1.55$ & $2.38 \pm 1.28$ & $2.83 \pm 1.46$ & $2.83 \pm 1.67$ & \\
\hline Elapsed time $(s)$ & $27.1 \pm 9.1$ & $27.4 \pm 9.0$ & $29.4 \pm 9.8$ & $33.2 \pm 14.1$ & \\
\hline \multicolumn{6}{|l|}{ Prazosin $(7.5 \mu g / k g)$} \\
\hline No. of attacks & $3.50 \pm 1.64$ & $2.83 \pm 1.45$ & $3.55 \pm 1.23$ & $3.33 \pm 1.62$ & \\
\hline Elapsed time $(s)$ & $35.0 \pm 11.0$ & $28.6 \pm 8.3$ & $35.9 \pm 9.3$ & $36.7 \pm 12.2$ & \\
\hline \multicolumn{6}{|l|}{ Prazosin $(25 \mu g / k g)$} \\
\hline No. of attacks & $2.20 \pm 0.90$ & $5.00 \pm 1.48$ & $4.88 \pm 1.78$ & $3.37 \pm 1.54$ & \\
\hline Elapsed time $(s)$ & $28.3 \pm 8.4$ & $44.3 \pm 11.4$ & $50.07 \pm 13.52$ & $38.2 \pm 12.2$ & \\
\hline \multicolumn{6}{|l|}{ Prazosin $(75 \mu g / k g)$} \\
\hline No. of attacks & $2.93 \pm 0.93$ & $11.43 \pm 2.76$ & $11.62 \pm 2.90$ & $9.77 \pm 1.35$ & (4) \\
\hline Elapsed time $(s)$ & $37.5 \pm 7.7$ & $125.0 \pm 33.2$ & $137.8 \pm 42.0$ & $73.4 \pm 11.5$ & (3) \\
\hline \multicolumn{6}{|l|}{ Prazosin $(225 \mu g / k g)$} \\
\hline No. of attacks & $3.00 \pm 1.37$ & $13.50 \pm 2.18$ & $14.25 \pm 1.59$ & $9.83 \pm 1.09$ & (3) \\
\hline Elapsed time $(s)$ & $35.2 \pm 13.30$ & $170.3 \pm 54.0$ & $203.9 \pm 39.3$ & $119.4 \pm 21.7$ & (6) \\
\hline \multicolumn{6}{|l|}{ Prazosin $(600 \mu g / k g)$} \\
\hline No. of attacks & $1.65 \pm 0.98$ & $14.15 \pm 2.08$ & $13.95 \pm 3.57$ & $10.05 \pm 2.79$ & $(5)$ \\
\hline Elapsed time $(s)$ & $33.6 \pm 13.8$ & $209.9 \pm 47.0$ & $169.3 \pm 52.3$ & $98.2 \pm 8.9$ & $(5)$ \\
\hline \multicolumn{6}{|c|}{ Methoxamine $(0.1 \mathrm{mg} / \mathrm{kg})$} \\
\hline No. of attacks & $3.92 \pm 0.97$ & $3.17 \pm 0.62$ & $3.33 \pm 1.26$ & $3.33 \pm 0.82$ & \\
\hline Elapsed time $(s)$ & $37.6 \pm 6.4$ & $45.3 \pm 8.4$ & $53.7 \pm 11.6$ & $35.0 \pm 7.2$ & \\
\hline \multicolumn{6}{|c|}{ Methoxamine $(0.2 \mathrm{mg} / \mathrm{kg})$} \\
\hline No. of attacks & $4.83 \pm 0.73$ & $3.00 \pm 1.11$ & $3.09 \pm 1.11$ & $3.25 \pm 1.23$ & \\
\hline Elapsed time $(s)$ & $67.0 \pm 12.1$ & $44.2 \pm 15.6$ & $39.1 \pm 11.7$ & $36.6 \pm 11.7$ & \\
\hline \multicolumn{6}{|c|}{ Methoxamine $(0.5 \mathrm{mg} / \mathrm{kg})$} \\
\hline No. of attacks & $4.10 \pm 1.64$ & $0.27 \pm 0.21$ & $0.27 \pm 0.21$ & $1.67 \pm 0.71$ & (1) \\
\hline Elapsed time $(s)$ & $39.2 \pm 9.9$ & $17.1 \pm 3.5$ & $13.2 \pm 1.3$ & $32.0 \pm 11.7$ & (2) \\
\hline \multicolumn{6}{|c|}{$\begin{array}{l}\text { Prazosin }(600 \mu g / \mathrm{kg}) \text { plus } \\
\text { methoxamine }(0.5 \mathrm{mg} / \mathrm{kg})\end{array}$} \\
\hline No. of attacks & $2.23 \pm 1.06$ & $12.73 \pm 2.62$ & $8.98 \pm 1.18$ & $5.83 \pm 0.83$ & (7) \\
\hline Elapsed time $(s)$ & $33.4 \pm 8.4$ & $206.6 \pm 56.0$ & $150.3 \pm 55.3$ & $81.1 \pm 13.2$ & (8) \\
\hline
\end{tabular}

Data shown are the mean \pm SEM of six dogs for each treatment. FECT and statistical procedures are described in Methods. A statistically significant prazosin dose-dependent increase in elapsed time and number of attacks was obtained $\left(P<10^{-9}\right)$. (1), $P<0.05$ vs. placebo; (2), $P<0.01$ vs. placebo; (3), $P<10^{-5}$ vs. placebo; (4), $P<10^{-6}$ vs. placebo; (5), $P<10^{-7}$ vs. placebo; (6), $P<10^{-8}$ vs. placebo; (7), $P<10^{-4}$ vs. $0.5 \mathrm{mg} / \mathrm{kg}$ methoxamine; (8), $P<10^{-8}$ vs. $0.5 \mathrm{mg} / \mathrm{kg}$ methoxamine.

floor, and partial in other cases (when the dog dropped to the ground on hindquarters, forequarters, or both, but with head above the floor). This test has been used previously with poodles and Dobermans and is very sensitive to drugs known to modify human narcolepsy (8).

Cardiovascular measurements. Systolic and diastolic BP (SBP and DBP) and HR were measured directly by an auscultatory method comparable to that described in reference 20 . The dogs were trained to stand quietly in a sling that supports most of their weight and did not show cataplexy during the measurements. BP was taken on the forelimb after detection of the humeral artery pulse. HR was taken by thoracic auscultation. Materials used included a child-size cuff, a diaphragm-type stethoscope, and a standard sphygmomanometer. 

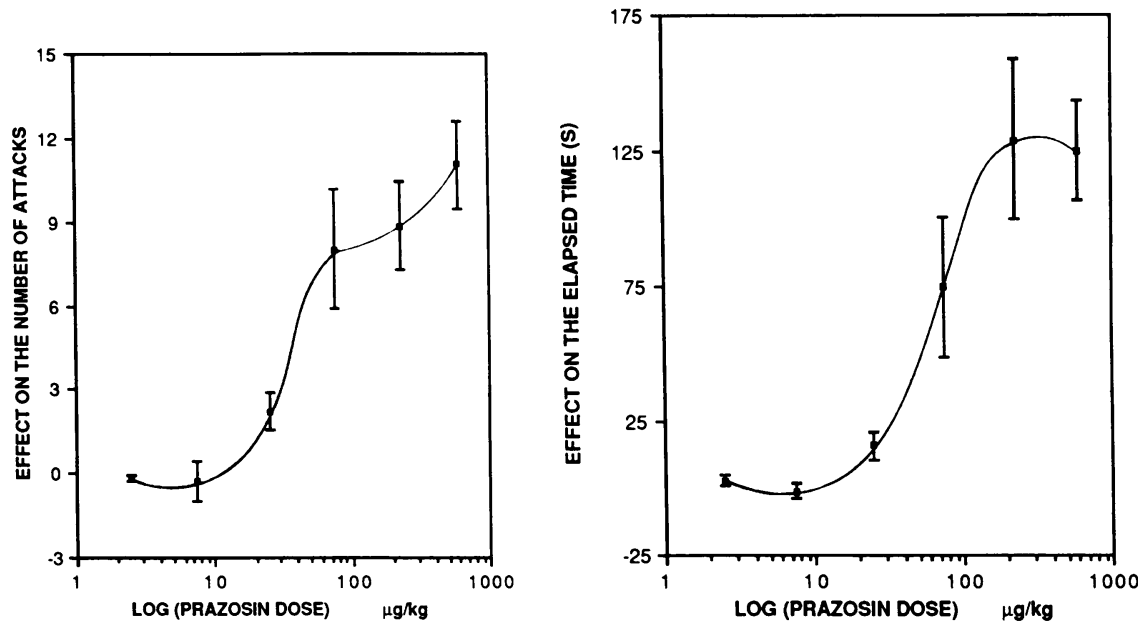

Figure 1. Dose-response curves of the effects of prazosin on cataplexy. Cataplexy was measured using the food-elicited cataplexy test (FECT, elapsed time and number of attacks) $(2,4$, and $8 \mathrm{~h})$ before and after drug administration. The dose dependence was examined on the mean of the three postdrug data points collected after various doses of prazosin $(2.5$, $7.5,25,75$, and $600 \mu \mathrm{g} / \mathrm{kg}$ p.o.). The term effect relates to the difference between pre- and postdrug values. Technical aspects are described in detail in the text. Each point is the mean of six narcoleptic dogs and vertical bars depict SEM.

Locomotor activity. To appreciate simultaneously the effects of the administered drugs on overall behavior of the dogs, an open field measurement of locomotor activity was also performed. The testing room was divided into squares of $\sim 50 \times 50 \mathrm{~cm}^{2}(\sim 25$ squares for the room used). The experimenter, located outside the room, watched the animal through the window for $2 \mathrm{~min} 30 \mathrm{~s}$ and recorded the number of times the dog's forelegs crossed a line separating two squares. The number and the duration of spontaneous cataplectic attacks that could occur during the test were recorded (under basal conditions these spontaneous attacks are unusual). The number of crossings was also expressed by minutes of wake ( 2 min $30 \mathrm{~s}$ - time spent in cataplexy) to exclude changes in this parameter due to an increase in cataplexy. This test was used to exclude any nonspecific effects and excessive sedation due to overdosage.

Experimental design. The FECT was administered (three tests in $20 \mathrm{~min}$; all subsequent data analysis used the mean of the three tests) before and after drug administration. Testing began at 9 a.m. and the experimenter who recorded the results was aware of the drug that had been given. Drugs were administered immediately after the first baseline testing of each dog (prazosin, hydralazine, methoxamine, and protriptyline) and/or $1 \mathrm{~h}$ later (metaraminol, dextroamphetamine, nisoxetine, atropine, and methylatropine). Postdrug FECTs were performed 2, 4, and $8 \mathrm{~h}$ after the first test in all the cases. Comparative control sessions were also performed by administrating placebo by way of the mouth (p.o.) and/or saline intramuscularly (two placebo sessions). BP, HR, and locomotor activity were measured with FECT administration during the first two tests $(t=0$ and $2 \mathrm{~h})$. Because the same dogs were used for several drug administration experiments, a correct washout (five times the half-life of the compound previously given) was always allowed.

Drugs. The following drugs were used for these experiments: prazosin $\mathrm{HCl}$ an alpha- 1 antagonist, ( 1 and $5 \mathrm{mg}$ Minipress, Pfizer Chemicals Div., Hoffman Estates, IL; $2.5-600 \mu \mathrm{g} / \mathrm{kg}$ p.o.), methoxamine $\mathrm{HCl}$, an alpha-1 agonist, (2\% Vasoxyl, Burroughs Wellcome \& Co., Raleigh, NC; $0.1-0.5 \mathrm{mg} / \mathrm{kg}$ i.m.), hydralazine $\mathrm{HCl}$, a peripheral vasodilator, (10 and $50 \mathrm{mg}$ Aprezoline, Ciba-Geigy Corp., Pharmaceuticals Div., Summit, NJ; $4 \mathrm{mg} / \mathrm{kg}$ p.o.), metaraminol bitartrate, a peripheral vasoconstrictor, (1\% Aramine, Merck Sharp \& Dohme, West Point, PA; $0.1 \mathrm{mg} / \mathrm{kg}$ i.m.), nisoxetine $\mathrm{HCl}$, a selective norepinephrine uptake inhibitor (Eli Lilly Research Laboratories, Indianapolis, IN; $0.5 \mathrm{mg} / \mathrm{kg}$ p.o.), protriptyline $\mathrm{HCl}$, a tricyclic antidepressant (5 and $10 \mathrm{mg}$ Vivactil, Merck Sharp \& Dohme, $1.2 \mathrm{mg} / \mathrm{kg}$ p.o.), dextroamphetamine sulfate, (an amphetamine, $5 \mathrm{mg}$ Dexedrine, SmithKline Corp., Philadelphia, PA; $0.5 \mathrm{mg} / \mathrm{kg}$ p.o.), atropine sulfate, an anticholinergic agent with central effect (Sigma Chemical Co., St. Louis, MO; $0.1 \mathrm{mg} / \mathrm{kg}$ i.m.), methylatropine nitrate, a peripheral anticholinergic drug (Sigma Chemical Co.; $0.1 \mathrm{mg} / \mathrm{kg}$ i.m.). Drugs (tablets, capsules, or powder) were given orally mixed with wet dog food or intramuscularly as obtained or dissolved in saline. Placebo sessions were performed by giving only the wet dog food (placebo session of the dose response curve of prazosin) or by giving wet dog food and one injection of $0.5 \mathrm{ml}$ saline i.m. $1 \mathrm{~h}$ later (placebo session of the drug combination experiments).

Statistics. Drug effects were analyzed using the computerized statistical program SYSTAT on an IBM XT computer (Systat Inc., Evanston, IL). Data were transformed (ranked) to obtain the homogeneity of variance within groups (Bartlett's test). Placebo and drugs sessions were compared by analysis of variance on repeated measures with grouping factors (treatment). One placebo session was used for prazosin dose-response analysis. The second placebo session was used for all the other comparisons. $P$ values of the univariate $F$ test statistics were considered only when they were in agreement with the results of the multivariate statistics (Wilks' Lambda likelihood ratio criterion, Pillia's Trace statistics, and Hotelling-Lawley trace and their corresponding $F$ statistics), which was the case most of the time. If the univariate and multivariate $F$ statistics led to different conclusions, the $P$ considered was the one obtained with the multivariate profile analysis (mean of the three tests) because this test does not require the compound symmetry assumption (equivalence of the covariances across all pairs of cells). The Bonferroni adjustment was applied to the $P$ values obtained in case of multiple comparisons.

Dose-response dependence of the prazosin effect was first tested as described previously, by analysis of variance using each dose and placebo as grouping factors. The second step used a simple linear regression between the effect of the drug on the parameter (postdrug-predrug values) and the log decimal of the prazosin dose. The dose dependence of the effect of prazosin on FECT was calculated on the mean of the three postdrug data points $(2,4$, and $8 \mathrm{~h})$ to condense the data. Maximal effects $\left(E_{\max }\right)$ and the doses producing $50 \%$ of the maximal effect $\left(E D_{50}\right)$ were approximated by nonlinear regression analysis on the following equation: effect $=E_{\max } /\left[\left(\mathrm{ED}_{50} /\right.\right.$ prazosin dose $\left.) \mu+1\right]$ with $\mu$ $=1$, according to Pliska (21). Minimization algorithms used were the Quasi-Newton method (Systat)

\section{Results}

Significance of the different parameters used in this study to quantify cataplexy. Four parameters directly assessed the severity of the cataplexy in narcoleptic dogs: the number of attacks and the elapsed time of the FECT were measures of elicited cataplexy and the number of spontaneous attacks and the time spent in cataplexy during the locomotor activity test were measures of spontaneous cataplexy. FECT elapsed time was highly correlated with the number of attacks occurring 
Table II. Effect of Placebo, Prazosin, and Methoxamine on Locomotor Activity and Spontaneous Cataplexy

\begin{tabular}{|c|c|c|c|c|c|}
\hline & & No. of crossings & No. of attacks & Time spent in cataplexy & $\begin{array}{l}\text { No. of crossings } \\
\text { per minute of wake }\end{array}$ \\
\hline & & & & $s$ & $\min ^{-1}$ \\
\hline \multicolumn{6}{|l|}{ Controls $(n=4)$} \\
\hline \multirow[t]{2}{*}{ Placebo } & Before & $60.1 \pm 9.4$ & - & - & $24.4 \pm 7.5$ \\
\hline & After & $61.4 \pm 10.7$ & - & - & $26.25 \pm 5.2$ \\
\hline \multirow[t]{2}{*}{ Prazosin $(600 \mu g / k g)$} & Before & $63.6 \pm 9.0$ & - & - & $25.5 \pm 3.6$ \\
\hline & After & $51.3 \pm 6.1$ & - & - & $20.0 \pm 2.4$ \\
\hline \multicolumn{6}{|l|}{ Heterozygotes $(n=4)$} \\
\hline \multirow[t]{2}{*}{ Placebo } & Before & $54.0 \pm 9.3$ & - & - & $21.6 \pm 3.7$ \\
\hline & After & $57.6 \pm 4.7$ & - & - & $23.0 \pm 1.9$ \\
\hline \multirow[t]{2}{*}{ Prazosin $(600 \mu g / k g)$} & Before & $57.5 \pm 7.2$ & - & - & $23.0 \pm 2.9$ \\
\hline & After & $62.5 \pm 10.9$ & - & - & $25.0 \pm 4.3$ \\
\hline \multicolumn{6}{|l|}{ Homozygotes $(n=6)$} \\
\hline \multirow[t]{3}{*}{ Placebo } & Before & $60.1 \pm 9.4$ & $0.17 \pm 0.17$ & $0.33 \pm 0.33$ & $24.2 \pm 3.8$ \\
\hline & After & $61.4 \pm 10.7$ & $0.08 \pm 0.08$ & $0.17 \pm 0.17$ & $24.6 \pm 4.3$ \\
\hline & & \multicolumn{4}{|c|}{$P<0.05$} \\
\hline \multirow[t]{2}{*}{ Prazosin $(2.5 \mu g / k g)$} & Before & $55.5 \pm 7.9$ & $0.75 \pm 0.04$ & $1.50 \pm 0.81$ & $22.4 \pm 3.2$ \\
\hline & After & $54.7 \pm 9.3$ & $0.33 \pm 0.21$ & $0.67 \pm 0.42$ & $22.0 \pm 3.8$ \\
\hline \multirow[t]{2}{*}{ Prazosin $(7.5 \mu g / k g)$} & Before & $75.5 \pm 6.0$ & $1.08 \pm 0.82$ & $5.25 \pm 2.14$ & $31.5 \pm 2.8$ \\
\hline & After & $67.5 \pm 4.3$ & $0.75 \pm 0.57$ & $1.50 \pm 1.15$ & $27.3 \pm 4.3$ \\
\hline \multirow[t]{2}{*}{ Prazosin $(25 \mu g / k g)$} & Before & $62.3 \pm 7.2$ & $1.50 \pm 1.31$ & $3.50 \pm 3.12$ & $25.6 \pm 3.0$ \\
\hline & After & $42.0 \pm 7.8$ & $1.50 \pm 1.15$ & $4.17 \pm 2.99$ & $17.2 \pm 3.1$ \\
\hline \multirow[t]{2}{*}{ Prazosin $(75 \mu g / k g)$} & Before & $51.5 \pm 11.0$ & $1.42 \pm 0.86$ & $4.67 \pm 2.13$ & $21.1 \pm 4.3$ \\
\hline & After & $37.0 \pm 4.2$ & $4.58 \pm 1.74^{*}$ & $45.58 \pm 18.97^{*}$ & $24.1 \pm 4.1$ \\
\hline \multirow[t]{2}{*}{ Prazosin $(225 \mu g / k g)$} & Before & $79.8 \pm 21.4$ & $0.50 \pm 0.22$ & $5.33 \pm 2.33$ & $29.6 \pm 7.2$ \\
\hline & After & $48.0 \pm 14.8$ & $1.50 \pm 0.72$ & $27.00 \pm 18.78^{*}$ & $20.9 \pm 6.4$ \\
\hline \multirow[t]{2}{*}{ Prazosin $(600 \mu g / k g)$} & Before & $60.3 \pm 6.5$ & $0.00 \pm 0.00$ & $0.00 \pm 0.00$ & $24.1 \pm 2.6$ \\
\hline & After & $33.8 \pm 2.7^{*}$ & $1.17 \pm 0.53^{*}$ & $19.92 \pm 5.33^{*}$ & $17.3 \pm 3.2$ \\
\hline \multirow[t]{2}{*}{ Methoxamine $(0.1 \mathrm{mg} / \mathrm{kg})$} & Before & $48.2 \pm 6.9$ & $0.50 \pm 0.34$ & $6.67 \pm 4.34$ & $20.5 \pm 3.2$ \\
\hline & After & $50.0 \pm 7.7$ & $0.50 \pm 0.22$ & $9.00 \pm 8.21$ & $21.0 \pm 2.7$ \\
\hline \multirow[t]{2}{*}{ Methoxamine $(0.2 \mathrm{mg} / \mathrm{kg})$} & Before & $59.0 \pm 13.7$ & $1.50 \pm 0.62$ & $21.33 \pm 8.76$ & $26.6 \pm 5.3$ \\
\hline & After & $57.0 \pm 14.5$ & $0.50 \pm 0.34$ & $19.00 \pm 17.83$ & $25.3 \pm 4.2$ \\
\hline \multirow[t]{2}{*}{ Methoxamine $(0.5 \mathrm{mg} / \mathrm{kg})$} & Before & $67.3 \pm 9.6$ & $0.58 \pm 0.41$ & $2.83 \pm 2.14$ & $27.5 \pm 3.8$ \\
\hline & After & $70.8 \pm 15.3$ & $1.00 \pm 0.68$ & $3.33 \pm 2.17$ & $28.8 \pm 6.0$ \\
\hline \multirow[t]{2}{*}{ Methoxamine plus prazosin } & Before & $61.1 \pm 10.1$ & $0.17 \pm 0.17$ & $0.33 \pm 0.33$ & $24.5 \pm 4.1$ \\
\hline & After & $35.6 \pm 7.9$ & $2.67 \pm 1.12^{\ddagger}$ & $37.00 \pm 15.78^{\ddagger}$ & $18.2 \pm 2.4$ \\
\hline
\end{tabular}

Data shown are the mean \pm SEM of six dogs for each treatment. Locomotor activity was measured using an open field divided into 25 squares (see Methods). The number of times the dogs crossed a line separating two squares in 2.5 min was counted. The raw number (number of crossings) was also expressed by minute of wake to distinguish changes in this parameter due to a change in cataplexy. The mean number and duration of spontaneous attacks that occurred during the test are also reported. Statistical analysis is described in Methods. $P<0.05$ : Statistical dose-dependent increase in spontaneous cataplexy after prazosin (overall analysis of variance on repeated measures with placebo and prazosin doses as grouping factors). ${ }^{*} P<0.05$ vs. placebo. ${ }^{\ddagger} P<0.05$ vs. methoxamine.

during all the drug-free tests (six dogs, $n=150, r^{2}=0.554, P$ $<10^{-9}$ ) with a constant (extrapolation of elapsed time when the number of attacks is zero) of $15.81 \pm 2.71 \mathrm{~s}$ (mean \pm SEM) and a slope (approximates the mean duration of one cataplectic attack) of $8.76 \pm 0.65 \mathrm{~s}$ (mean \pm SEM). Similarly, the time spent in cataplexy during the locomotor activity procedure was correlated with its corresponding number of attacks during the same drug-free tests $\left(n=150, r^{2}=0.184, P<10^{-7}\right)$. The drug-free number of attacks during FECT (elicited cataplexy) was also slightly correlated with the time spent in cata- plexy during the locomotor activity test (spontaneous cataplexy) $\left(n=150, r^{2}=0.035, P<0.05\right)$.

Effect of prazosin on the cataplexy of homozygous Dobermans. The first compound tested on cataplexy was prazosin, a very selective alpha-1 adrenergic receptor antagonist $(22,23)$ that easily crosses the blood brain barrier (24). Prazosin is the most potent cataplexy-inducing compound we have yet tested. Dosages as low as $75 \mu \mathrm{g} / \mathrm{kg}$ p.o. lead to a long-lasting (up to 8 h) exacerbation of cataplexy during FECT (number of attacks and elapsed time, Table I) in all homozygous Dobermans 
Table III. Cardiovascular Changes Induced by Prazosin and Methoxamine

\begin{tabular}{|c|c|c|c|c|}
\hline & & Heart rate & SBP & DBP \\
\hline & & beats/min & & \\
\hline \multicolumn{5}{|l|}{ Controls $(n=4)$} \\
\hline \multirow[t]{2}{*}{ Placebo } & Before & $115.0 \pm 4.0$ & $170.0 \pm 4.0$ & $108.8 \pm 9.2$ \\
\hline & After & $122.8 \pm 2.6$ & $170.0 \pm 7.9$ & $105.0 \pm 7.4$ \\
\hline \multirow[t]{2}{*}{ Prazosin $(600 \mu g / k g)$} & Before & $120.0 \pm 4.1$ & $165.0 \pm 6.5$ & $106.3 \pm 11.1$ \\
\hline & After & $137.5 \pm 7.8$ & $147.5 \pm 10.3^{*}$ & $81.3 \pm 6.6^{\ddagger}$ \\
\hline \multicolumn{5}{|l|}{ Heterozygotes $(n=4)$} \\
\hline \multirow[t]{2}{*}{ Placebo } & Before & $126.0 \pm 2.7$ & $175.0 \pm 11.9$ & $93.8 \pm 3.8$ \\
\hline & After & $126.0 \pm 1.2$ & $177.5 \pm 10.9$ & $92.5 \pm 6.3$ \\
\hline \multirow[t]{2}{*}{ Prazosin $(600 \mu g / k g)$} & Before & $121.5 \pm 4.1$ & $172.5 \pm 8.5$ & $95.0 \pm 6.5$ \\
\hline & After & $151.5 \pm 6.9$ & $147.5 \pm 11.1^{\ddagger}$ & $72.5 \pm 4.8^{\ddagger}$ \\
\hline \multicolumn{5}{|l|}{ Homozygotes $(n=6)$} \\
\hline \multirow[t]{3}{*}{ Placebo } & Before & $126.8 \pm 6.0$ & $171.7 \pm 8.3$ & $98.3 \pm 8.2$ \\
\hline & After & $123.3 \pm 9.9$ & $171.7 \pm 8.0$ & $101.7 \pm 7.6$ \\
\hline & & $P<0.05$ & $P<0.01$ & $P<0.05$ \\
\hline \multirow[t]{2}{*}{ Prazosin $(2.5 \mu g / k g)$} & Before & $108.8 \pm 6.1$ & $178.3 \pm 10.1$ & $92.5 \pm 4.8$ \\
\hline & After & $115.0 \pm 6.7$ & $177.5 \pm 8.2$ & $95.8 \pm 5.4$ \\
\hline \multirow{2}{*}{ Prazosin $(7.5 \mu g / k g)$} & Before & $127.7 \pm 7.1$ & $181.7 \pm 8.0$ & $86.7 \pm 4.4$ \\
\hline & After & $125.7 \pm 7.1$ & $175.0 \pm 7.5$ & $86.7 \pm 4.0$ \\
\hline \multirow{2}{*}{ Prazosin $(25 \mu g / k g)$} & Before & $120.0 \pm 10.2$ & $184.2 \pm 7.0$ & $90.0 \pm 4.3$ \\
\hline & After & $116.0 \pm 11.4$ & $179.2 \pm 6.6$ & $83.3 \pm 5.6$ \\
\hline \multirow[t]{2}{*}{ Prazosin $(75 \mu g / k g)$} & Before & $136.0 \pm 10.1$ & $169.2 \pm 8.1$ & $92.5 \pm 4.2$ \\
\hline & After & $160.0 \pm 8.5^{*}$ & $156.7 \pm 4.9$ & $85.0 \pm 5.0$ \\
\hline \multirow[t]{2}{*}{ Prazosin $(225 \mu g / k g)$} & Before & $132.0 \pm 8.5$ & $179.2 \pm 9.3$ & $87.5 \pm 4.0$ \\
\hline & After & $178.0 \pm 10.2^{*}$ & $157.5 \pm 6.8^{*}$ & $74.2 \pm 3.3^{\ddagger}$ \\
\hline \multirow[t]{2}{*}{ Prazosin $(600 \mu g / k g)$} & Before & $119.8 \pm 7.6$ & $165.0 \pm 4.1$ & $96.7 \pm 7.4$ \\
\hline & After & $135.7 \pm 8.4^{*}$ & $141.7 \pm 6.9^{\ddagger}$ & $81.7 \pm 7.6^{*}$ \\
\hline \multirow[t]{2}{*}{ Methoxamine $(0.1 \mathrm{mg} / \mathrm{kg})$} & Before & $130.0 \pm 5.9$ & $177.5 \pm 7.9$ & $100.8 \pm 6.9$ \\
\hline & After & $141.0 \pm 10.2$ & $174.2 \pm 7.8$ & $90.0 \pm 3.4$ \\
\hline \multirow[t]{2}{*}{ Methoxamine $(0.2 \mathrm{mg} / \mathrm{kg})$} & Before & $136.0 \pm 9.1$ & $175.8 \pm 10.0$ & $89.2 \pm 4.2$ \\
\hline & After & $110.0 \pm 9.5$ & $181.7 \pm 11.2$ & $98.3 \pm 1.7$ \\
\hline \multirow[t]{2}{*}{ Methoxamine $(0.5 \mathrm{mg} / \mathrm{kg})$} & Before & $122.0 \pm 8.4$ & $170.0 \pm 5.9$ & $96.7 \pm 1.7$ \\
\hline & After & $115.0 \pm 9.7$ & $174.2 \pm 6.3$ & $101.7 \pm 4.0$ \\
\hline \multirow{2}{*}{$\begin{array}{l}\text { Methoxamine }(0.5 \mathrm{mg} / \mathrm{kg}) \text { plus } \\
\text { prazosin }(600 \mu \mathrm{g} / \mathrm{kg})\end{array}$} & Before & $118.3 \pm 4.1$ & $175.8 \pm 6.2$ & $89.2 \pm 4.4$ \\
\hline & After & $115.3 \pm 10.2$ & $171.7 \pm 6.1^{\S}$ & $88.3 \pm 4.2$ \\
\hline
\end{tabular}

Data shown are the mean \pm SEM. Systolic and diastolic BP and HR were taken by an auscultatory method. Schedules of drug administration and statistical procedures are described in the text. $P<0.05$ and $P<0.01$ : Statistical dose-dependent changes in HR and BP (overall analysis of variance on repeated measures with placebo and prazosin doses as grouping factors). ${ }^{*} P<0.05$ vs. placebo. ${ }^{\ddagger} P<0.01$ vs. placebo.

${ }^{\S} P<0.05$ vs. prazosin.

tested. Prazosin even triggered attacks in the oldest animal of our group, who normally showed no cataplexy during FECT. The dose dependence of the effect of prazosin on FECT was calculated on the mean of the three postdrug data points collected after various doses of prazosin $(2.5-600 \mu \mathrm{g} / \mathrm{kg})$. This mean effect is shown on Fig. 1. A high correlation was obtained between the effect of prazosin on the number of attacks or the elapsed time and the logarithm of the prazosin dose [number of attacks vs. $\log$ (dose of prazosin): $n=36$ (six dogs $\times$ six doses), $r^{2}=0.760, P<10^{-9}$; elapsed time vs. $\log$ (dose of prazosin): $n=36, r^{2}=0.702, P<10^{-9}$ ]. Estimations of the maximal effects and $\mathrm{ED}_{50}$ for the number of attacks were $E_{\max }$ $=12.49$ attacks, $\mathrm{ED}_{50}=73.55 \mu \mathrm{g} / \mathrm{kg}$ (correlation between pa- rameters estimates $r=0.787, n=36$ ) and for elapsed time were $E_{\max }=159.9 \mathrm{~s}, \mathrm{ED}_{50}=97.61 \mu \mathrm{g} / \mathrm{kg}$ (correlation between parameters estimates $r=0.800, n=36$ ). Prazosin was also able to increase the number of cataplectic attacks and the time spent in cataplexy during simple observation without emotional stimuli (locomotor activity measurements, Table II). The drug also produced a significant decrease in the number of line crossings by the narcoleptic dogs during the locomotor activity test (Table II), but the effect disappeared when the number of crossings was corrected for the time the dogs were awake (Table II). A correlation was obtained between the effect of a given dose of prazosin on the number of attacks or the time spent in cataplexy during the locomotor activity test and 
Table IV. Cardiovascular Effects of Monoaminergic and Cholinergic Drugs

\begin{tabular}{|c|c|c|c|c|}
\hline & & HR & SBP & DBP \\
\hline & & beats/min & & \\
\hline \multirow[t]{2}{*}{ Placebo } & Before & $125.8 \pm 5.3$ & $168.3 \pm 6.3$ & $94.2 \pm 4.9$ \\
\hline & After & $130.2 \pm 9.7$ & $168.8 \pm 4.6$ & $95.4 \pm 3.4$ \\
\hline \multirow[t]{2}{*}{ Prazosin $(600 \mu g / k g)$} & Before & $119.8 \pm 7.6$ & $165.0 \pm 4.1$ & $96.7 \pm 7.4$ \\
\hline & After & $135.7 \pm 8.4^{*}$ & $141.7 \pm 6.9^{\ddagger}$ & $81.7 \pm 7.6^{*}$ \\
\hline \multirow[t]{2}{*}{ Hydralazine } & Before & $122.0 \pm 2.7$ & $175.0 \pm 11.9$ & $93.3 \pm 8.1$ \\
\hline & After & $236.9 \pm 16.4^{8}$ & $146.7 \pm 8.7^{*}$ & $70.6 \pm 4.5^{*}$ \\
\hline \multirow[t]{2}{*}{ Metaraminol } & Before & $119.0 \pm 6.8$ & $165.8 \pm 8.9$ & $86.7 \pm 3.3$ \\
\hline & After & $91.0 \pm 7.0^{*}$ & $193.3 \pm 4.0^{*}$ & $112.5 \pm 8.6^{*}$ \\
\hline \multirow[t]{2}{*}{ Metaraminol $+\mathbf{P z}$} & Before & $127.0 \pm 9.4$ & $170.8 \pm 9.5$ & $95.8 \pm 4.4$ \\
\hline & After & $112.3 \pm 9.4$ & $172.5 \pm 8.3^{\prime \prime}$ & $89.2 \pm 3.8$ \\
\hline \multirow[t]{2}{*}{ Nisoxetine } & Before & $131.0 \pm 8.1$ & $176.7 \pm 9.6$ & $79.2 \pm 4.9$ \\
\hline & After & $130.0 \pm 9.9$ & $179.2 \pm 9.4$ & $75.0 \pm 1.8$ \\
\hline \multirow[t]{2}{*}{ Nisoxetine $+\mathrm{Pz}$} & Before & $126.0 \pm 8.2$ & $174.2 \pm 14.0$ & $81.7 \pm 6.0$ \\
\hline & After & $150.0 \pm 8.8^{\prime \prime}$ & $145.0 \pm 8.5$ & $63.3 \pm 4.8$ \\
\hline \multirow[t]{2}{*}{ Protriptyline } & Before & $137.0 \pm 10.5$ & $177.5 \pm 11.2$ & $77.5 \pm 3.1$ \\
\hline & After & $128.0 \pm 10.5$ & $185.0 \pm 13.2$ & $85.0 \pm 6.7$ \\
\hline \multirow[t]{2}{*}{ Protriptyline $+\mathbf{P z}$} & Before & $133.0 \pm 12.3$ & $186.7 \pm 9.1$ & $79.2 \pm 4.9$ \\
\hline & After & $178.7 \pm 16.6^{* *}$ & $154.2 \pm 9.5$ & $70.0 \pm 5.0$ \\
\hline \multirow[t]{2}{*}{ Dextroamphetamine } & Before & $128.7 \pm 11.7$ & $175.0 \pm 9.2$ & $90.8 \pm 4.9$ \\
\hline & After & $134.3 \pm 20.8$ & $192.5 \pm 8.0^{*}$ & $96.7 \pm 5.9$ \\
\hline \multirow[t]{2}{*}{ Dextroamphetamine $+\mathrm{Pz}$} & Before & $128.0 \pm 10.8$ & $179.2 \pm 11.6$ & $93.3 \pm 4.8$ \\
\hline & After & $161.0 \pm 16.3$ & $170.8 \pm 12.5^{\prime \prime}$ & $84.2 \pm 2.7$ \\
\hline \multirow[t]{2}{*}{ Atropine } & Before & $132.7 \pm 12.5$ & $175.0 \pm 10.3$ & $96.7 \pm 8.7$ \\
\hline & After & $207.0 \pm 22.1^{\ddagger}$ & $164.2 \pm 8.4$ & $96.7 \pm 4.9$ \\
\hline \multirow[t]{2}{*}{ Atropine $+\mathrm{Pz}$} & Before & $129.7 \pm 13.2$ & $166.7 \pm 11.4$ & $94.2 \pm 5.2$ \\
\hline & After & $190.0 \pm 17.5$ & $145.8 \pm 7.1$ & $79.2 \pm 2.7$ \\
\hline \multirow[t]{2}{*}{ Methylatropine } & Before & $123.7 \pm 9.2$ & $173.3 \pm 10.4$ & $90.0 \pm 5.3$ \\
\hline & After & $243.3 \pm 26.7^{\ddagger \ddagger}$ & $182.5 \pm 14.7$ & $105.0 \pm 4.1$ \\
\hline \multirow[t]{2}{*}{ Methylatropine $+\mathrm{Pz}$} & Before & $119.3 \pm 13.9$ & $169.2 \pm 9.0$ & $95.8 \pm 3.3$ \\
\hline & After & $221.3 \pm 16.2$ & $141.7 \pm 8.4$ & $79.2 \pm 3.3$ \\
\hline
\end{tabular}

Data shown are the mean \pm SEM of six narcoleptic dogs for each treatment. BP and HR were taken by an auscultatory method. Schedules of drug administration and statistical procedures are described in the text. $\mathrm{Pz},{ }^{*} P<0.05$ vs. placebo. ${ }^{\ddagger} P<0.01$ vs. placebo. ${ }^{8} P<0.001$ vs. placebo. " $P<0.05$ vs. prazosin. ' $P<0.05$ vs. nisoxetine. ${ }^{* *} P<0.05$ vs. protriptyline. ${ }^{\ddagger \ddagger} P<10^{-4}$ vs. placebo.

the logarithm of the prazosin dose [number of attacks vs. log (dose of prazosin): $n=36, r^{2}=0.270, P<0.001$; time spent in cataplexy vs. $\log$ (dose of prazosin): $n=36, r^{2}=0.256, P$ $<0.01$ ]. Estimations of the maximal effects and $\mathrm{ED}_{50}$ for the number of attacks were $E_{\max }=1.71$ attacks, $\mathrm{ED}_{50}=30.99$ $\mu \mathrm{g} / \mathrm{kg}$ (correlation between parameters estimates $r=0.833, n$ $=36$ ) and for time spent in cataplexy were $E_{\max }=28.13 \mathrm{~s}$, $\mathrm{ED}_{50}=35.34 \mu \mathrm{g} / \mathrm{kg}$ (correlation between parameters estimates $r=0.644, n=36$ ).

Effect of prazosin on BP and $H R$. Prazosin taken orally produced a dose-dependent decrease in SBP and DBP and a dose-dependent increase in HR (Table III). Estimations of the maximal effects and $\mathrm{ED}_{50}$ for SBP, DBP, and $\mathrm{HR}$ were, respectively, $E_{\max }=27.00 \mathrm{mmHg}, \mathrm{ED}_{50}=75.59 \mu \mathrm{g} / \mathrm{kg}$ (correlation between parameters estimates $r=0.913, n=36), E_{\max }=17.06$ $\mathrm{mmHg}, \mathrm{ED}_{50}=74.22 \mu \mathrm{g} / \mathrm{kg}$ (correlation between parameters estimates $r=0.748, n=36$ ), and $E_{\max }=33.88$ beats $/ \mathrm{min}$, $\mathrm{ED}_{50}=60.32 \mu \mathrm{g} / \mathrm{kg}$ (correlation between parameters estimates $r=0.616, n=36) .600 \mu \mathrm{g} / \mathrm{kg}$ prazosin p.o. also produced a statistical decrease in SBP and DBP and an increase in HR in the control and heterozygous Dobermans (Table III). The magnitude of changes appeared similar in the three groups of animals (homozygous, heterozygous, and control dogs) (Table III).

Effect of prazosin on FECT in control and heterozygous Dobermans. Prazosin had a noticeable effect on BP (see above) and control experiments were then needed to eliminate the role of the cardiovascular system in the effect observed on FECT. Control and heterozygous Dobermans did not present any spontaneous or emotionally induced cataplectic attacks and were able to eat all the pieces of food in $<20 \mathrm{~s}$ (Table I and II). Prazosin, at a dose of $600 \mu \mathrm{g} / \mathrm{kg}$ (7 to 20 times the $\mathrm{ED}_{50}$ in narcoleptic dogs), did not produce any cataplectic attacks in these normal dogs, despite the fact that potent vasodilation and hypotension were observed (Table III) as a consequence of the blockade of alpha-1 vascular receptors (25).

Effect of BP changes on cataplexy. That hypotension did not induce cataplexy in normal dogs did not, however, exclude 

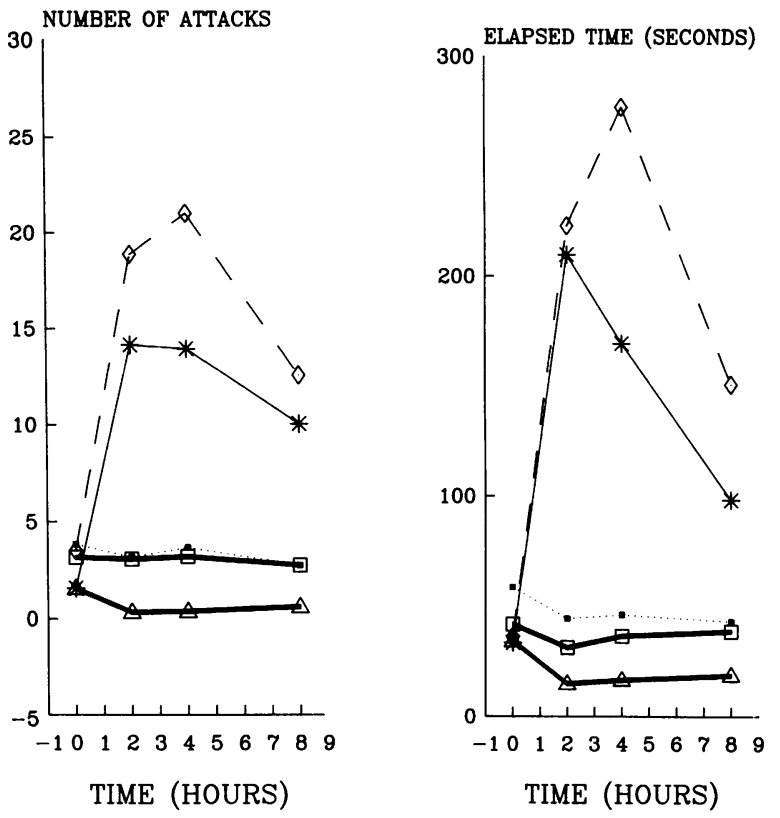

Figure 2. Effect of placebo, prazosin $(600 \mu \mathrm{g} / \mathrm{kg} \mathrm{p.o.),} \mathrm{metaraminol}$ $(0.1 \mathrm{mg} / \mathrm{kg}$ i.m.), or prazosin plus metaraminol on cataplexy in homozygous Dobermans. Cataplexy was measured using the FECT (see Methods and Fig. 1). Data shown are the mean of 6 narcoleptic Dobermans for each treatment. SEM have been omitted for the clarity of the figure. Placebo, prazosin (Pz), and hydralazine were given per $o s$ just after the baseline testing $(t=0 \mathrm{~h})$. Metaraminol was injected intramuscularly $1 \mathrm{~h}$ after the first testing. Comparisons between groups were made using analysis of variance. Statistical procedures are described in detail in Methods. Number of attacks: $P<10^{-7}$ prazosin vs. placebo; $P<0.05$ hydralazin vs. placebo; $P<10^{-6} \mathrm{Pz}$ + metaraminol vs. metaraminol. Elapsed time: $P<10^{-7}$ prazosin vs. placebo; $P<10^{-5} \mathrm{Pz}+$ metaraminol vs. metaraminol. $\rightarrow$, prazosin; $€$, placebo; $\varangle$, hydralazine; $\rightarrow \cdot, \mathrm{pz}+$ metaraminol; $\cdots \cdot \cdots$, metaraminol.

the possibility that changes in BP might improve or aggravate cataplexy in the narcoleptic Dobermans. Some complementary experiments directly addressed this issue. We examined the effect of peripheral vasoconstriction induced by metaraminol, an alpha-1 stimulant with no central effect (26-28) on cataplexy. Administration of metaraminol induced hypertension and bradycardia (Table IV) and did not change cataplexy (Fig. 2), demonstrating that peripheral alpha-1 stimulation does not explain the beneficial effects of methoxamine. We also tried to dissociate the central from the peripheral alpha-1 effects by administering prazosin in the absence and presence of metaraminol to counteract the hypotensive effect of prazosin (25). The two drug regimens effectively normalized the blood pressure (Table IV), whereas the aggravation of spontaneous and food-elicited cataplexy induced by prazosin persisted (Fig. 2, Table V). These results demonstrate that the peripheral cardiovascular effects have little participation in the overall anticataplectic effect of the centrally acting drugs described in this work. A last control experiment examined the effect of another potent hypotensive agent, hydralazine (29), on cataplexy. Administration of hydralazine induced hypotension and tachycardia (Table IV) without large changes in cataplexy (Fig. 2). A statistically significant improvement was even noticed after hydralazine administration (Fig. 2).
Effect of methoxamine alone and associated with prazosin. Methoxamine was selected as a central alpha-1 receptor agonist because it crosses the blood brain barrier (13) and has been reported to have some effect on $\operatorname{REM}$ sleep $(14,30)$. Methoxamine also has some other pharmacological properties, such as a beta-blocking action (27), which cannot be neglected in vivo. Methoxamine improved number of attacks and elapsed time on the FECT when administered at $0.5 \mathrm{mg} / \mathrm{kg}$ i.m. (Table I). A combination of methoxamine $(0.5 \mathrm{mg} / \mathrm{kg}$ i.m. $)$ and prazosin $(600 \mu \mathrm{g} / \mathrm{kg}$ p.o.) did not modify blood pressure and HR (Table III), but did increase elicited and spontaneous cataplexy similar to that obtained with prazosin alone (Table I and II), confirming the alpha-1 mediation of the methoxamine effect (Tables I and II).

Effect of dextroamphetamine, nisoxetine, and protriptyline alone and associated with prazosin. Dextroamphetamine alone significantly decreased cataplexy during FECT (Fig. 3), increased locomotor activity (number of crossings, even when corrected for the time spent in cataplexy and sleep/number of crossings by minute of wake) (Table V) and produced systolic hypertension (Table IV). Nisoxetine and protriptyline also decreased food-elicited cataplexy (Fig. 3) but did not change cardiovascular parameters and locomotor activity significantly (Table IV and V). Dextroamphetamine, nisoxetine, or protriptyline when combined with prazosin $(600 \mu \mathrm{g} / \mathrm{kg}$ p.o.) produced a large increase of spontaneous and elicited cataplexy similar to the one obtained with prazosin alone (Fig. 3, Table V). Coadministration of dextroamphetamine with prazosin also reduced the hypotension produced by the alpha-1 blocking agent (Table IV).

Effect of prazosin in combination with atropine and methylatropine. As expected from the literature, atropine, which crosses the blood-brain barrier, ameliorated food-elicited cataplexy (Fig. 4, Table V), whereas methylatropine, a peripheral anticholinergic drug, was ineffective on FECT (Fig. 4). Both compounds produced tachycardia but did not modify significantly SBP or DBP (Table IV). The aggravating effect of prazosin $(600 \mu \mathrm{g} / \mathrm{kg}$ p.o.) on elicited and spontaneous cataplexy was completely abolished by a coadministration of atropine (Fig. 4, Table V) and the combination of both drugs even improved the dogs, as did atropine alone (Fig. 4). On the other hand, methylatropine, when associated with prazosin, did not modify the prazosin effect, and the combination of both drugs aggravated the dogs, as did prazosin alone (Fig. 4). Atropine and methylatropine both produced a similar tachycardia when associated with prazosin (Table IV).

\section{Discussion}

Alpha-1 adrenoceptors are widely distributed within the central nervous system (31), but little is known about their physiological role. Alpha-1 adrenergic agents have no overt central effects in waking animals $(26,32,33)$ and humans (34), and reports conflict over their effects on REM sleep $(12-16,30)$. Our data demonstrate a crucial role of these receptors in canine narcolepsy, which is considered an animal model of human narcolepsy.

The canine disorder, documented since 1973, presents striking clinical similarities to its human counterpart. The animals have been shown to be abnormally sleepy $(18,19)$ and to have fragmented sleep/wake patterns (19). Furthermore, the dogs show loss of muscle tone during feeding, playing, or sex- 
Table V. Effect of Monoaminergic and Cholinergic Drugs on Locomotor Activity and Spontaneous Cataplexy

\begin{tabular}{|c|c|c|c|c|c|}
\hline & & No. of crossings & No. of attacks & Time spent in cataplexy & $\begin{array}{l}\text { No. of crossings per } \\
\text { minute of wake }\end{array}$ \\
\hline & & & & $s$ & $\min ^{-1}$ \\
\hline \multirow[t]{2}{*}{ Placebo } & Before & $62.3 \pm 9.6$ & $0.92 \pm 0.46$ & $5.92 \pm 3.9$ & $26.4 \pm 4.4$ \\
\hline & After & $46.5 \pm 9.1$ & $0.63 \pm 0.30$ & $5.92 \pm 3.2$ & $19.5 \pm 3.9$ \\
\hline \multirow[t]{2}{*}{ Prazosin $(600 \mu g / k g)$} & Before & $60.3 \pm 6.5$ & $0.00 \pm 0.00$ & $0.00 \pm 0.00$ & $24.1 \pm 2.6$ \\
\hline & After & $33.8 \pm 2.7^{*}$ & $1.17 \pm 0.53^{*}$ & $19.92 \pm 5.33^{*}$ & $17.3 \pm 3.2$ \\
\hline \multirow[t]{2}{*}{ Hydralazine } & Before & $75.5 \pm 14.4$ & $0.17 \pm 0.11$ & $0.33 \pm 0.21$ & $30.3 \pm 5.7$ \\
\hline & After & $70.0 \pm 14.5$ & $0.08 \pm 0.08$ & $0.17 \pm 0.17$ & $28.1 \pm 5.8$ \\
\hline \multirow[t]{2}{*}{ Metaraminol } & Before & $64.7 \pm 10.5$ & $0.83 \pm 0.40$ & $11.00 \pm 7.31$ & $32.4 \pm 4.8$ \\
\hline & After & $59.8 \pm 6.8$ & $1.50 \pm 0.72$ & $10.67 \pm 5.55$ & $31.4 \pm 3.1$ \\
\hline \multirow[t]{2}{*}{ Metaraminol $+\mathbf{P z}$} & Before & $73.7 \pm 14.3$ & $1.42 \pm 1.23$ & $22.25 \pm 17.2$ & $36.4 \pm 5.8$ \\
\hline & After & $24.5 \pm 4.4$ & $3.08 \pm 0.97^{\ddagger}$ & $43.83 \pm 19.0$ & $16.8 \pm 2.1$ \\
\hline \multirow[t]{2}{*}{ Nisoxetine } & Before & $71.2 \pm 9.7$ & $0.33 \pm 0.11$ & $10.67 \pm 6.77$ & $30.1 \pm 3.2$ \\
\hline & After & $84.4 \pm 17.2$ & $0.00 \pm 0.00$ & $0.00 \pm 0.00$ & $33.8 \pm 6.9$ \\
\hline \multirow[t]{2}{*}{ Nisoxetine $+\mathbf{P z}$} & Before & $71.7 \pm 8.5$ & $0.33 \pm 0.21$ & $5.33 \pm 3.51$ & $30.0 \pm 3.9$ \\
\hline & After & $33.3 \pm 8.3$ & $1.83 \pm 0.78^{\S}$ & $34.17 \pm 15.89^{\prime \prime}$ & $17.4 \pm 3.0$ \\
\hline \multirow[t]{2}{*}{ Protriptyline } & Before & $79.0 \pm 10.7$ & $0.67 \pm 0.33$ & $6.50 \pm 3.91$ & $33.2 \pm 4.9$ \\
\hline & After & $78.3 \pm 10.1$ & $0.33 \pm 0.21$ & $6.67 \pm 6.28$ & $33.2 \pm 4.4$ \\
\hline \multirow[t]{2}{*}{ Protriptyline $+\mathrm{Pz}$} & Before & $63.5 \pm 8.7$ & $0.00 \pm 0.00$ & $0.00 \pm 0.00$ & $25.4 \pm 3.2$ \\
\hline & After & $43.7 \pm 12.1$ & $2.17 \pm 1.01^{\prime}$ & $40.17 \pm 11.45^{\pi}$ & $25.3 \pm 6.9$ \\
\hline \multirow[t]{2}{*}{ Dextroamphetamine } & Before & $64.2 \pm 10.3$ & $0.67 \pm 0.49$ & $5.00 \pm 3.26$ & $26.5 \pm 4.0$ \\
\hline & After & $117.7 \pm 22.0^{* *}$ & $0.00 \pm 0.00$ & $0.00 \pm 0.00$ & $47.1 \pm 8.8^{\ddagger \ddagger}$ \\
\hline \multirow[t]{2}{*}{ Dextroamphetamine $+\mathrm{Pz}$} & Before & $58.7 \pm 12.9$ & $1.75 \pm 1.01$ & $12.42 \pm 7.54$ & $26.1 \pm 5.8$ \\
\hline & After & $18.2 \pm 1.2^{\S \S}$ & $7.58 \pm 3.00^{\prime I I I}$ & $75.42 \pm 19.21^{1 I I I I}$ & $21.1 \pm 5.6$ \\
\hline \multirow[t]{2}{*}{ Atropine } & Before & $78.8 \pm 11.9$ & $1.58 \pm 1.05$ & $3.83 \pm 2.43$ & $32.4 \pm 4.8$ \\
\hline & After & $78.5 \pm 7.9$ & $0.08 \pm 0.08$ & $0.17 \pm 0.17$ & $31.4 \pm 3.1$ \\
\hline \multirow[t]{2}{*}{ Atropine $+\mathrm{Pz}$} & Before & $56.0 \pm 9.1$ & $1.50 \pm 0.88$ & $5.83 \pm 3.38$ & $23.8 \pm 4.5$ \\
\hline & After & $63.8 \pm 4.4^{\pi T}$ & $0.25 \pm 0.25^{* * *}$ & $0.50 \pm 0.50^{\ddagger \ddagger \ddagger}$ & $25.6 \pm 1.8$ \\
\hline \multirow[t]{2}{*}{ Methylatropine } & Before & $59.2 \pm 10.1$ & $0.92 \pm 0.58$ & $1.83 \pm 1.17$ & $24.0 \pm 4.0$ \\
\hline & After & $57.2 \pm 11.8$ & $0.67 \pm 0.49$ & $1.33 \pm 0.99$ & $23.0 \pm 4.7$ \\
\hline \multirow[t]{2}{*}{ Methylatropine $+\mathrm{Pz}$} & Before & $60.7 \pm 6.9$ & $0.33 \pm 0.25$ & $0.67 \pm 0.49$ & $24.4 \pm 2.8$ \\
\hline & After & $54.7 \pm 14.4$ & $2.58 \pm 1.25^{* * *}$ & $16.92 \pm 9.01^{* * *}$ & $25.8 \pm 7.5$ \\
\hline
\end{tabular}

Data shown are the mean \pm SEM of six narcoleptic dogs. Methods and statistical procedures are described in legend to Table II. ${ }^{*} P<0.05$ vs. placebo. ${ }^{\ddagger} P<0.05$ vs. metaraminol. ${ }^{8} P<0.05$ vs. nisoxetine. " $P<0.01$ vs. nisoxetine. " $P<0.01$ vs. protriptyline. ${ }^{* *} P<0.01$ vs. placebo. ${ }^{\sharp} P<0.05$ vs. placebo. ${ }^{\$} P<10^{-5}$ vs. amphetamine. $\quad$ IIII $P<10^{-4}$ vs. amphetamine. $" P<0.05$ vs. atropine. ${ }^{* * *} P<0.05$ vs. methylatropine. ${ }^{\ddagger \ddagger} P<0.05$ vs. prazosin.

ual intercourse, a state akin to human cataplexy and similarly generated in an emotional context $(8,17)$. A familial pattern of narcolepsy has been clearly established in humans but the genetic mechanisms are poorly understood. The causes may be multifactorial, or a single dominant gene with low penetrance may be involved. The canine syndrome is known to affect various breeds of dogs with different genetic mechanisms (8). Doberman pinschers and Labrador retrievers transmit narcolepsy to their offspring through an autosomal recessive mechanism. Narcoleptic poodles and Dobermans are improved by the classical treatments used in human narcolepsy (8).

That prazosin and methoxamine respectively aggravate and improve cataplexy suggested central alpha-1 adrenergic control of canine narcolepsy, but additional experiments were needed to exclude any participation of peripheral alpha-1 blockade in the observed effects. We therefore showed that prazosin was still able to elicit cataplexy under normal blood pressure conditions (when associated with peripheral sympathomimetic drugs) and that administration of another hypotensive agent, hydralazine, did not increase cataplexy. A slight improvement of cataplexy was even obtained after hydralazine. A possible explanation of this observation may be found in the recent work of Lai et al. (7). These authors have examined the effect of pharmacological manipulations of blood pressure on muscle hypotonia induced by stimulation of the medial medulla in the decerebrate cat (generally considered akin to REM sleep loss of motor tone). Experiments were also performed on a single narcoleptic dog. The findings of Lai et al. indicate a beneficial effect of blood pressure decrease on both medial medulla-induced muscle atonia and cataplexy. These results implicate a role of the autonomic cardiovascular system in the expression of cataplexy and confirmed that the effects observed after prazosin are not due to peripheral alpha1 blockade. 
ELAPSED TIME (SECONDS)

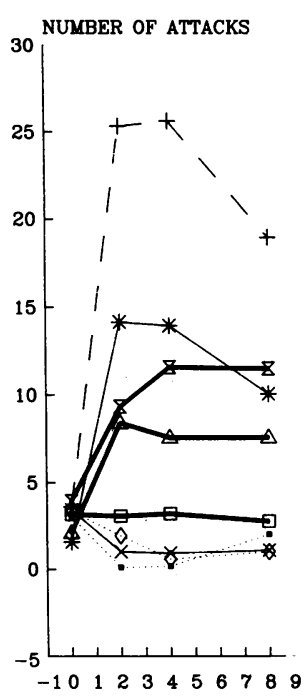

TIME (HOURS)

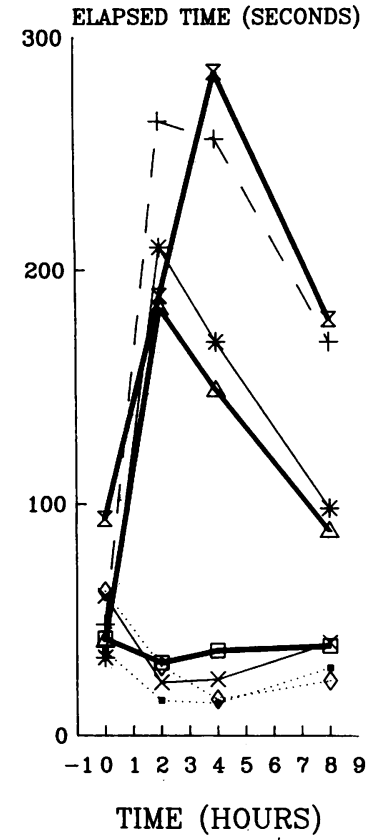

Figure 3. Effect of placebo, dextroamphetamine $(0.5 \mathrm{mg} / \mathrm{kg}$ p.o. $)$, nisoxetine $(0.5 \mathrm{mg} / \mathrm{kg}$ p.o.), and protriptyline $(1.2 \mathrm{mg} / \mathrm{kg} \mathrm{p.o}$.) alone and in combination with prazosin $(600 \mu \mathrm{g} / \mathrm{kg}$ p.o.) on cataplexy in narcoleptic Dobermans. Prazosin $(\mathrm{Pz})$ and protriptyline were administered just after the first test. Nisoxetine and dextroamphetamine were given $1 \mathrm{~h}$ after the first testing. Data are the mean of six dogs for each treatment. Methods are described in the legend to Fig. 1 and in the text. Number of attacks: $P<10^{-7}$ prazosin vs. placebo; $P$ $<0.001$ dextroamphetamine vs. placebo; $P<0.05$ nisoxetine vs. placebo; $P<0.05$ protriptyline vs. placebo; $P<10^{-4} \mathrm{Pz}+$ protriptyline vs. protriptyline; $P<0.001, \mathrm{Pz}+$ protriptyline vs. prazosin; $P<10^{-8}$ $\mathrm{Pz}+$ dextroamphetamine vs. dextroamphetamine; $P<10^{-7} \mathrm{Pz}+$ nisoxetine vs. nisoxetine. Elapsed time: $P<10^{-7}$ prazosin vs. placebo; $P<0.01$ dextroamphetamine vs. placebo; $P<0.05$ nisoxetine vs. placebo; $P<0.01$ protriptyline vs. placebo; $P<10^{-8} \mathrm{Pz}+$ protriptyline vs. protriptyline; $P<10^{-8} \mathrm{Pz}+$ dextroamphetamine vs. dextoamphetamine; $P<10^{-8} \mathrm{Pz}+$ nisoxetine vs. nisoxetine. $\rightarrow$, prazosin; $甘$, placebo; $\cdots \cdot \cdots$, dextroamphetamine; $\rightarrow \cdot$, pz + d-amphetamine; $*$, nisoxetine; $\cdots \diamond \cdots$, , protriptyline; $\star$, pz + protriptyline; $₹, \mathrm{pz}+$ nisoxetine.

We also antagonized the effect of some classical nonspecific therapeutic agents (amphetamine, protriptyline, and nisoxetine) with prazosin, suggesting that, as proposed in the rationale of the study, these drugs could improve narcolepsy by a presynaptic increase in central noradrenergic activity, which then stimulates alpha-1 receptors.

The importance of pontine central cholinergic transmission in REM sleep regulation has been extensively investigated by general pharmacology and local brainstem stimulation (2-7). Cholinergic neurons of the dorsal pontine tegmentum tonically inhibit muscle tone during REM sleep $(2-3,7)$. Consistent with these anatomical findings, central cholinergic stimulation by physostigmine or arecoline has been reported to aggravate the symptoms in narcoleptic dogs, whereas central anticholinergic drugs, such as atropine or scopolamine, improve them (8). This well-known effect of atropine is shown in Fig. 4 in our group of narcoleptic dogs. This effect is centrally mediated, since methylatropine, a selective peripheral
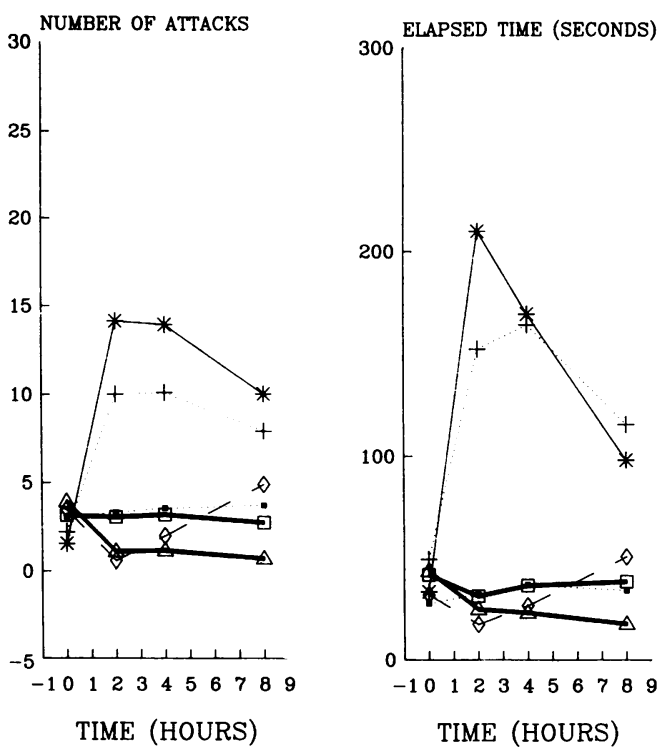

Figure 4. Effect of placebo, atropine $(0.1 \mathrm{mg} / \mathrm{kg}$ i.m.), and methylatropine $(0.1 \mathrm{mg} / \mathrm{kg}$ i.m. $)$ alone and in combination with prazosin $(600 \mu \mathrm{g} / \mathrm{kg}$ p.o.) on cataplexy in narcoleptic Dobermans. Prazosin (Pz) was administered just after the first test. Atropine and methylatropine were given $1 \mathrm{~h}$ after the first testing. Data are the mean of six dogs for each treatment. Methods are described in the legend to Fig. 1 and in the text. Number of attacks: $P<10^{-7}$ prazosin vs. placebo; $P<0.05$ atropine vs. placebo; $P<10^{-8} \mathrm{Pz}+$ atropine vs. prazosin; $P$ $<0.001 \mathrm{Pz}+$ methylatropine vs. methylatropine. Elapsed time: $P$ $<10^{-7}$ prazosin vs. placebo; $P<10^{-8} \mathrm{Pz}+$ atropine vs. prazosin; $P$ $<0.01 \mathrm{Pz}+$ methylatropine vs. methylatropine. $\rightarrow$, prazosin; $\because$, placebo; $\_$, atropine; $\rightarrow \cdot, \mathrm{pz}+$ atropine; $\cdots \cdot \cdots$, methylatropine; $\cdots+\cdots, \mathrm{pz}+$ methylatropine.

anticholinergic drug, does not modify FECT (Fig. 4). If alpha-1 adrenergic receptors are mainly implicated in narcolepsy, one may ask whether these mechanisms are integrated with these cholinergic mechanisms (i.e., does the monoaminergic system control the cholinergic system or do both systems work in parallel and independently?). To answer this question, we examined the coadministration of prazosin with both atropine and methylatropine, to rule out any peripheral interaction. Atropine, but not methylatropine, completely suppressed the effects of prazosin (Fig. 4). The integrity of a central cholinergic synapse thus is needed for the expression of prazosin effects.

A role for norepinephrine in REM sleep regulation has been documented for many years (9-11). Our data increase the understanding of this monoaminergic control. The very drastic impact of prazosin on our dogs has to be emphasized again: it is the most potent drug that we have ever manipulated. It induces a state close to the human status cataplecticus (1). We also provide evidence for a unknown physiological role of central alpha- 1 adrenoceptors: the control of cataplexy, a pathological manifestation of the physiological REM sleep atonia. Results of this work should stimulate the search for more specific alpha-1 adrenergic central agents. These compounds, if available, could improve human narcolepsy treatment and might help us to understand and manipulate abnormal REM sleep patterns of other pathologies, such as depression. 


\section{Acknowledgments}

We thank the Stanford Department of Laboratory Animal Medicine for technical support and supervision of animal care, Neuron Data (Palo Alto, CA) for providing computer resources, and Don Bliwise for assistance with the statistics. Discussions with T. Kilduff, B. Hayes, R. Dean, and B. Nouchi helped the development of this work.

The study was supported by grant NS-19572 from the National Institutes of Health, by a grant from the American Narcolepsy Association, and by Lafon Laboratories (Maisons Alfort, France).

\section{References}

1. Guilleminault, C., P. Passouant, and W. C. Dement. 1976. Narcolepsy. Spectrum Publications, New York. 664 pp.

2. Hobson, J. A., M. Goldberg, E. Vivaldi, and D. Riew. 1983. Enhancement of desynchronized sleep signs after pontine microinjection of muscarinic agonist bethinechol. Brain Res. 275:127-136.

3. Pompeiano, O. 1985. Cholinergic mechanisms involved in the gain regulation of postural reflexes. In Sleep: Neurotransmitters and Neuromodulators. A. Wauquier, J. M. Monti, J. M. Gaillard, and M. Radulovacki, editors. Raven Press, New York. 165-184.

4. Baghdoyan, H. A., R. W. McCarley, and J. A. Hobson. 1985. Cholinergic manipulation of brainstem reticular systems: effects on desynchronized sleep generation. In Sleep: Neurotransmitters and Neuromodulators. A. Wauquier, J. M. Monti, J. M. Gaillard, and M. Radulovacki, editors. Raven Press, New York. 15-27.

5. Gillin, J. C., N. Sitaram, D. Janowsky, C. Rish, L. Huey, and F. I. Storch. 1985. Cholinergic mechanisms in REM sleep. In Sleep: Neurotransmitters and Neuromodulators. A. Wauquier, J. M. Monti, J. M. Gaillard, and M. Radulovacki, editors. Raven Press, New York. 29-42.

6. Sakai, K. 1985. Neurons responsible for paradoxical sleep. In Sleep: Neurotransmitters and Neuromodulators. A. Wauquier, J. M. Monti, J. M. Gaillard, and M. Radulovacki, editors. Raven Press, New York. 29-42.

7. Lai, Y. Y., J. M. Siegel, and W. J. Wilson. 1987. Effect of blood pressure on medial medulla-induced muscle atonia. Am. J. Physiol. 252:H1249-H1257.

8. Baker, T. L., and W. C. Dement. 1985. Canine narcolepsy-cataplexy syndrome: evidence for an inherited monoaminergic cholinergic imbalance. In Brain Mechanism of Sleep. D. J. Mc Ginty, editor. Raven Press, New York. 199-233.

9. Jouvet, M. 1969. Biogenic amines and the states of sleep. Science (Wash. DC). 163:32-41.

10. Hartmann, E., R. Chung, P. R. Draskoczy, and J. J. Schildkraut. 1971. Effects of 6-hydroxydopamine on sleep in the rat. Nature (Lond.). 223:425-427.

11. Monti, J. M. 1983. Catecholamines and the sleep-wake cycle, REM. Sleep. 32:1401-1415.

12. Hartmann, E., and G. Zwilling. 1976. The effect of alpha and beta adrenergic receptor blockers on sleep in the rat. Pharmacol. Biochem. Behav. 5:135-138.

13. Pickworth, W. B., L. G. Sharpe, M. Nozaki, and W. R. Martin. 1977. Sleep suppression induced by intravenous and intraventricular infusions of methoxamine in the dog. Exp. Neurol. 57:999-1011.

14. Hiliakivi, I., and A. Leppavuori. 1984. Effects of methoxamine, an alpha- 1 adrenocepteur agonist and prazosin, an alpha-1 antagonist on the stages of the sleep-waking cycle in the cat. Acta Physiol. Scand. 120:363-372.

15. Leinonen, L., and D. Stenberg. 1986. Sleep in macaca arctoides and the effects of prazosin.Physiol. Behav. 37:199-202.

16. Oswald, I., V. R. Thacore, K. Adam, V. Brezinová, and R. Burack. 1975. Alpha-adrenergic receptor blockade increases human REM sleep. Eur. J. Clin. Pharmacol. 2:107-110.

17. Kushida, C. A., T. L. Baker, and W. C. Dement. 1985. Electroencephalographic correlates of cataplectic attacks in narcoleptic canines. Electroencephalogr. Clin. J. 61:61-71.

18. Kaitin, K. H., T. S. Kilduff, andَ W. C. Dement. 1986. Evidence for excessive sleepiness in canine narcolepsy. Electroencephalogr. Clin. Neurophysiol. 64:447-454.

19. Kaitin, K. H., T. S. Kilduff, and W. C. Dement. 1986. Sleep fragmentation in canine narcolepsy. Sleep. 9:116-119.

20. Geddes, L. A. 1970. Measurements in dogs. In The Direct and Indirect Measurement of Blood Pressure. L. A. Geddes, editor. Year Book Medical Publishers Inc., Chicago, IL. 150-158.

21. Pliska, V. 1987. Dose-response models: similarity with population growth dynamics. Trends Pharmacol. Sci. 8:50-52,

22. Greengrass, P., and R. Bremmer. 1979. Binding characteristics of 3 H-Prazosin to rat brain alpha-adrenergic receptors. Eur. J. Pharmacol. 55:323-326.

23. Starke, K. 1981. Alpha-adrenoceptor subclassification. Rev. Physiol. Pharmacol. 88:200-236.

24. Menkes, D. B., C. K. Aghahajanian, and D. W. Gallager. 1983. Chronic antidepressant treatment enhances agonist affinity of brain alpha-1 adrenoceptors. Eur. J. Pharmacol. 37:35-41.

25. Constantine, J. W., W. K. McShane, B. S. A. Scriabine, and H. J. Hess. 1973. Analysis of the hypotensive action of prazosin. In Hypertension: Mechanisms and Management. G. Onesti, K. E. Kim, and J. H. Moyer, editors. Grune and Stratton, Inc., New York/London. 429-444.

26. Nozaki, M., J. A. Bell, and W. R. Martin. 1980. Noradrenergic action of amphetamine following degeneration of descending monoaminergic fibers in the spinal cord. Psychopharmacology. 67:25-29.

27. Gilman, A. G., and L. S. Goodman. 1985. The Pharmacological Basis of Therapeutics. Macmillan Book Co., New York. 1,839 pp.

28. Eckstein, J. W., and F. M. Abboud. 1962. Circulatory effects of sympathomimetic amines. Am. Heart J, 63:119-135.

29. Druey, J., and J. Tripod. 1967. Hydralazines. In Antihypertensive Agents. E. Schlittler, editor. Academic Press, New York. 237-262.

30. Pellejero, T., J. M. Monti, J. Baglietto, H. Jantos, S. Pazos, V. Cichevski, and M. Hawkins. 1984. Effects of methoxamine and alpha adrenoceptors antagonists, prazosin and yohimbine, on the sleep-wake cycle of the rat. Sleep. 7:365-372.

31. Young, W. S., and M. J. Kuhar. 1980. Noradrenergic alpha-1 and alpha-2 receptors light microscopic autoradiographic localization. Proc. Natl. Acad. Sci. USA. 77:1696-1700.

32. Menon, M. K., C. K. Kodama, A. S. Kling, and J. Fitten. 1986. An in vivo pharmacological method for the quantitative evaluation of the central effects of alphal adrenoceptor agonists and antagonists. Neuropharmacology. 25:503-508.

33. Pichler, L., and W. Kobinger. 1985. Possible functions of alpha 1-adrenoceptors in the CNS in anaesthetized and conscious animals. Eur. J. Pharmacol. 107:305-311.

34. Stanaszek, W. F., D. Kellerman, R. N. Brogden, and J. A. Romankiewicz. 1983. Prazosin update. Drugs. 25:339--384. 